\title{
Catalytic synthesis of 2-methylpyrazine over Cr-promoted copper based catalyst via a cyclo-dehydrogenation reaction route
}

\author{
FANGLI JING, YUANYUAN ZHANG, SHIZHONG LUO*, WEI CHU*, HUI ZHANG \\ and XINYU SHI \\ Department of Chemical Engineering, Sichuan University, NO. 24 South Section 1, Yihuan Road, \\ Chengdu 610065, China \\ e-mail: luoszscu@gmail.com, chuwei65@yahoo.com.cn
}

MS received 14 May 2009; revised 4 October 2009; accepted 15 October 2009

\begin{abstract}
The cyclo-dehydrogenation of ethylene diamine and propylene glycol to 2-methylpyrazine was performed under the atmospheric conditions at $380^{\circ} \mathrm{C}$. The $\mathrm{Cr}$-promoted $\mathrm{Cu}-\mathrm{Zn} / \mathrm{Al}_{2} \mathrm{O}_{3}$ catalysts were prepared by impregnation method and characterized by ICP-AES, $\mathrm{N}_{2}$ adsorption/desorption, XRD, XPS, $\mathrm{N}_{2} \mathrm{O}$ chemisorption, TPR and $\mathrm{NH}_{3}$-TPD techniques. The amorphous chromium species existing in $\mathrm{Cu}-\mathrm{Zn}-\mathrm{Cr} / \mathrm{Al}_{2} \mathrm{O}_{3}$ catalyst enhanced the dispersion of active component $\mathrm{Cu}$, promoted the reduction of catalyst. Furthermore, the catalytic performance was significantly improved. The acidity of the catalyst played an important role in increasing the 2-MP selectivity. To optimize the reaction parameters, influences of different chromium content, reaction temperature, liquid hourly space velocity (LHSV), reactants molar ratio and time on stream on the product pattern were studied. The results demonstrated that addition of chromium promoter revealed satisfying catalytic activity, stability and selectivity of 2-methylpyrazine.
\end{abstract}

Keywords. 2-Methylprazine; copper-based catalyst; chromium-promoter; ethylene diamine; propylene glycol; characterization.

\section{Introduction}

Pyrazine and its derivatives are valuable compounds because of their application in the synthesis of perfumery, pharmaceutical and agricultural chemical industries. $^{1-3}$ As an example, 2-methylpyrazine (2-MP), an important lower alkyl-substituted pyrazine, is widely used as a key intermediate for pyrazineamide, an effective anti-tubercular drug. ${ }^{4,5}$ Currently, 2-methylpyrazine is prepared by dehydration-cyclization and/or partial dehydrogenation of ethylene diamine (ED) and propylene glycol (PG). ${ }^{6}$ Forni and Pollesel $^{7}$ studied the mechanism of the cyclization of ethylene diamine and propylene glycol to 2-methylpyrazine by means of the TPD-TPRMS technique. They pointed out that the reaction involves a Rideal-Eley mechanism leading to a fully hydrogenated intermediate 2-methylpiperazine between adsorbed propylene glycol and gaseous ethylene diamine. The mechanism is shown in scheme 1. Catalytic systems based on zinc, ${ }^{8}$ zinc-chromium, ${ }^{9}$

\footnotetext{
*For correspondence
}

copper-chromium ${ }^{10}$ and $\mathrm{Ag}^{11}$ were patented. Other catalysts such as $\mathrm{ZnO}-\mathrm{MoO}_{3}, \mathrm{ZnO}-\mathrm{V}_{2} \mathrm{O}_{5}, \mathrm{Zn}-\mathrm{WO}_{3}{ }^{12}$ $\mathrm{ZnO}-\mathrm{MnSO}_{4}-\mathrm{H}_{3} \mathrm{PO}_{4}{ }^{13} \mathrm{Ag}-\mathrm{La}-\mathrm{Zn} / \mathrm{Al}_{2} \mathrm{O}_{3}, \mathrm{Ag}-\mathrm{Pt} / \mathrm{Al}_{2} \mathrm{O}_{3}$, and $\mathrm{Ag}-\mathrm{Mg} / \mathrm{Al}_{2} \mathrm{O}_{3},{ }^{14} \mathrm{Pd}$-promoted $\mathrm{ZnO} / \mathrm{Zn}-\mathrm{Cr}-\mathrm{O}$ catalysts, ${ }^{15}$ zinc-modified ferrierite (FER), ${ }^{16}$ H-ZSM-5, zinc-modified zeolite catalysts (including ZSM-5 and Beta) ${ }^{17}$ were also used for synthesis of 2-methylpyrazine.

The catalysts containing chromium were extensively used for dehydrogenation of piperazine to pyrazine, ${ }^{18,19}$ which indicated that catalysts containing chromium promoted effectively on the dehydrogenation reaction. Park et $a l^{20,21}$ reported that metal (copper, nickel, cobalt) oxide-modified $\mathrm{ZnO} / \mathrm{SiO}_{2}$ for cyclo-dehydrogenation of ethylene diamine with propylene glycol to 2-methylpyrazine, demonstrated that the metallic copper and zinc oxide were assigned to dehydrogenation and dehydration, respectively. Since the catalytic synthesis of 2methylpyrazine is related with cyclization (dehydration) and dehydrogenation of piperazine intermediate, the catalysts which should possess dual functional active sites, they have been designed, 


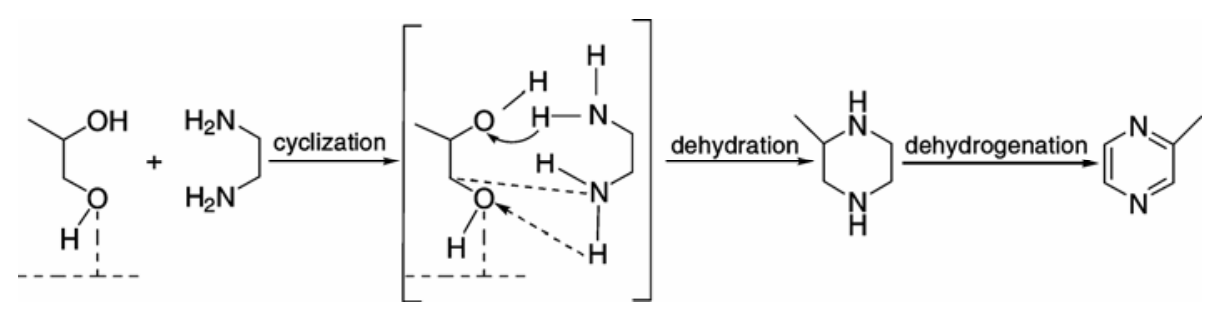

Scheme 1. Reaction pathway for the synthesis of 2-methylpyrazine from ethylene diamine and propylene glycol.

prepared and measured for 2-methylpyrazine synthesis.

In this work, a novel type bifunctional $\mathrm{Cr}$ promoted $\mathrm{Cu}-\mathrm{Zn} / \mathrm{Al}_{2} \mathrm{O}_{3}$ oxide catalyst was proposed, characterized using inductively coupled plasmaatomic emission spectrometry (ICP-AES), X-ray diffraction (XRD), X-ray photoelectron spectra (XPS), $\mathrm{N}_{2} \mathrm{O}$ chemisorption, etc. methods, to understand the chemical composition, the structure, the chemical state of elements and $\mathrm{Cu}$ surface area and dispersion of the catalyst and correlated these physicochemical properties with its performance.

\section{Experimental}

\subsection{Catalyst preparation}

The $\mathrm{Cu}-\mathrm{Zn}-\mathrm{Cr}_{x} / \mathrm{Al}_{2} \mathrm{O}_{3}$ catalysts were prepared by a 3 -step-impregnation method. Appropriate amount of $\mathrm{Cu}\left(\mathrm{NO}_{3}\right)_{2} \cdot 3 \mathrm{H}_{2} \mathrm{O}, \mathrm{Zn}\left(\mathrm{NO}_{3}\right)_{2} \cdot 6 \mathrm{H}_{2} \mathrm{O}$ and $\mathrm{Cr}\left(\mathrm{NO}_{3}\right)_{3}$ $9 \mathrm{H}_{2} \mathrm{O}$ were dissolved in $9 \mathrm{~mL}$ deionized water as impregnating solution. The one third solution was uniformly added drop-wise on $3 \mathrm{~g}$ alumina support (40-60 mesh, pre-treated at $450^{\circ} \mathrm{C}$ for $4 \mathrm{~h}$ ), for $10 \mathrm{~min}$, and then dried at $110^{\circ} \mathrm{C}$ for $20 \mathrm{~min}$. Repeating above operations 2 more times, then it was dried at $110^{\circ} \mathrm{C}$ for $4 \mathrm{~h}$ and calcined at $450^{\circ} \mathrm{C}$ for $5 \mathrm{~h}$. For the comparison, the $\mathrm{Cu} / \mathrm{Al}_{2} \mathrm{O}_{3}$ and $\mathrm{Cu}-\mathrm{Zn} / \mathrm{Al}_{2} \mathrm{O}_{3}$ catalysts were prepared in the same way.

\subsection{Catalyst characterization}

The ICP-AES IRIS Advantage (TJA Solution, USA) was employed to determine the chemical compositions of the different catalyst samples by inductively coupled plasma atomic emission spectroscopy technique.

The surface area, total pore volume and average pore diameter were measured by the $\mathrm{N}_{2}$ adsorption/desorption, using a Quantachrome Nova $1000 \mathrm{e}$ apparatus at liquid nitrogen temperature. Samples were degassed at $300^{\circ} \mathrm{C}$ for $3 \mathrm{~h}$ prior to analysis.

$\mathrm{X}$-ray diffraction (XRD) tests were performed on DX-100 diffractometer with $\mathrm{CuK} \alpha$ radiation, scanning $2 \theta$ angles in the range of $20-80^{\circ}$.

X-ray photoelectron spectra (XPS) were recorded with XSAM800 spectrometer with an $\mathrm{AlK} \alpha$ $(1486.6 \mathrm{eV})$ radiation.

Temperature-programmed reduction (TPR) measurements were carried out at atmospheric pressure in a fixed-bed. $50 \mathrm{mg}$ sample was loaded in a quartz reactor in $\mathrm{N}_{2}$ flow at $50^{\circ} \mathrm{C}$ for $30 \mathrm{~min}$. Then the nitrogen was replaced by the reductive gas $(5 \%$ $\mathrm{H}_{2} / \mathrm{N}_{2}$ ) at a flow rate of $30 \mathrm{~mL} / \mathrm{min}$. The temperature of the reactor was increased linearly from 100 to $550^{\circ} \mathrm{C}$ at a rate of $10^{\circ} \mathrm{C} / \mathrm{min}$ by a temperatureprogrammed controller. The effluent stream was analysed by a thermal conductivity detector (TCD).

$\mathrm{Cu}$ surface area, particles size and the metal dispersion were measured by $\mathrm{N}_{2} \mathrm{O}$ passivation method including a two-step analysis: $\mathrm{N}_{2} \mathrm{O}$ oxidization surface $\mathrm{Cu}$ to $\mathrm{Cu}_{2} \mathrm{O}$ and $\mathrm{H}_{2}$ temperature-programmed reduction of the formed $\mathrm{Cu}_{2} \mathrm{O}$ surface species. ${ }^{22,23} \mathrm{~A}$ fresh $50 \mathrm{mg}$ catalyst was pre-reduced at $350^{\circ} \mathrm{C}$ (rising the temperature at a rate of $10^{\circ} \mathrm{C} / \mathrm{min}$ ) for $1 \mathrm{~h}$ in $\mathrm{H}_{2} / \mathrm{N}_{2}$ mixture gas flow ( $5 \mathrm{vol} . \%$ at $30 \mathrm{~mL} / \mathrm{min}$ ). The temperature was in situ cooled to the adsorption temperature $60^{\circ} \mathrm{C}$ in pure $\mathrm{N}_{2}$ flow $(40 \mathrm{~mL} / \mathrm{min})$ and then the reduced-catalyst was exposed to the pure $\mathrm{N}_{2} \mathrm{O}(30 \mathrm{~mL} / \mathrm{min})$ for $1 \mathrm{~h}$ to oxidize the metallic $\mathrm{Cu}$ to $\mathrm{Cu}_{2} \mathrm{O}$. After $\mathrm{N}_{2} \mathrm{O}$ passivation, the catalyst was purged with $\mathrm{N}_{2}(40 \mathrm{~mL} / \mathrm{min})$ to remove the residual oxidant and subsequently the second TPR was performed to reduce $\mathrm{Cu}_{2} \mathrm{O}$ to $\mathrm{Cu}$. The $\mathrm{H}_{2}$ consumption in the two procedures was monitored by TCD and calculated quantitatively from the TPR peak area, calibrated with standard $\mathrm{CuO}$ samples.

The acidity of the calcined catalyst was characterized by temperature-programmed desorption of ammonia $\left(\mathrm{NH}_{3}-\mathrm{TPD}\right)$ techniques. $50 \mathrm{mg}$ catalyst sample, loading in the middle of quartz tube, was 


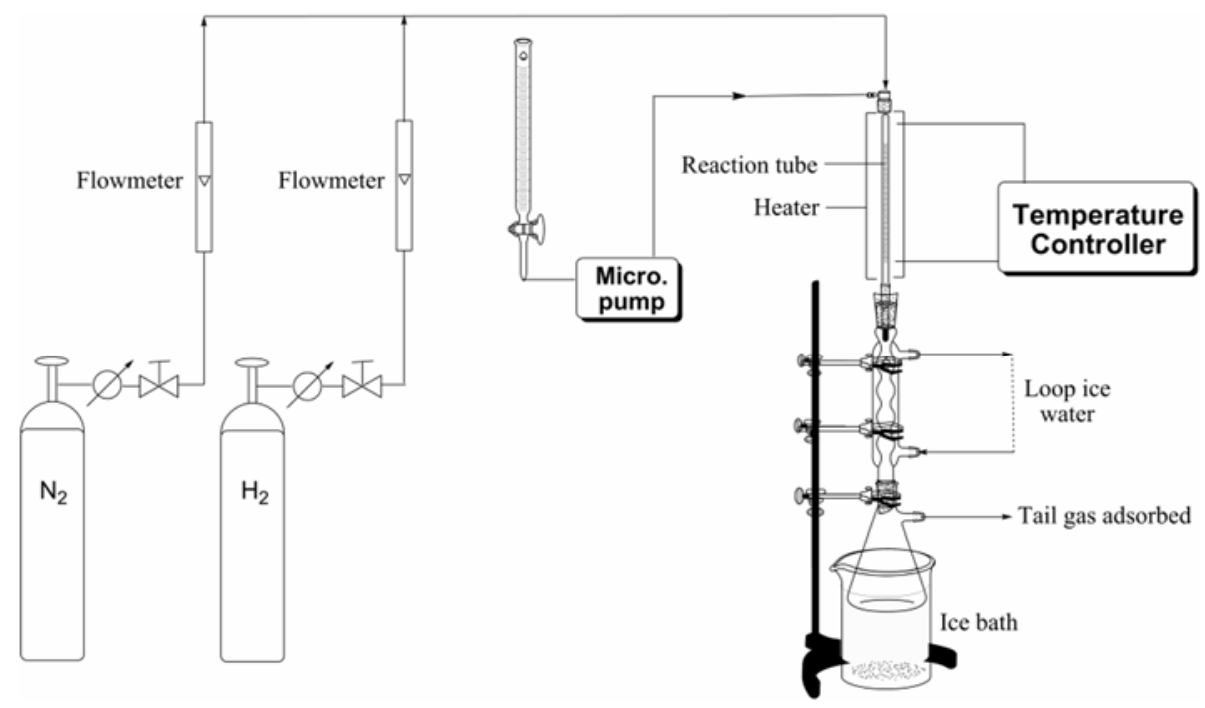

Figure 1. The reaction apparatus for synthesis of 2-methylpyrazine.

used for $\mathrm{NH}_{3}-\mathrm{TPD}$. Prior to analysis the sample was pre-treated in situ in an Ar flow $(30 \mathrm{~mL} / \mathrm{min})$ at $380^{\circ} \mathrm{C}$ for $2 \mathrm{~h}$, then cooled to the $\mathrm{NH}_{3}$ adsorption temperature $100^{\circ} \mathrm{C} . \mathrm{NH}_{3}$ was absorbed by a pulsed injection in an Ar flow until saturation which was determined by the TCD signal. The TPD profiles were monitored by a thermal conductivity detector and recorded from 100 to $700^{\circ} \mathrm{C}$ at a heating rate of $10^{\circ} \mathrm{C} / \mathrm{min}$.

\subsection{Catalytic performance in synthesis of 2-methylpyrazine}

The catalytic activity measurements of the calcined catalysts were performed at atmospheric pressure in a continuous fixed-bed reactor (stainless steel, $8 \mathrm{~mm}$ i.d., $300 \mathrm{~mm}$ length). The reaction apparatus was showed in figure 1 . The catalyst was loaded at the middle of the reaction tube with a packing height of $60 \mathrm{~mm}$, reduced under the $\mathrm{H}_{2}$ and $\mathrm{N}_{2}$ gas mixture flow $\left(\mathrm{H}_{2} / \mathrm{N}_{2}=1\right.$, molar ratio) at $380^{\circ} \mathrm{C}$ for $2 \mathrm{~h}$ and then reacted at the same temperature. The aqueous liquid reactants were prepared by mixing ethylene diamine and propylene glycol in the mole ratio of $1: 1$, and diluted with deionized water (50 wt.\%). Dilution with water was helpful for reducing the viscosity and smooth feeding of the reactants. The liquid reactants were injected into the top-side of reactor by a pump at $3 \mathrm{~mL} / \mathrm{h}$ and the pure nitrogen $(25 \mathrm{~mL} / \mathrm{min})$ was introduced as dilute gas. The liquid products were collected in an ice-water condenser and analysed by gas chromatography (GC-
112A) using a capillary column (cross-linked SE-30 gum, $0.33 \mathrm{~mm} \times 30 \mathrm{~m}$ ) and flame ionization detector (FID). The identification of the liquid products was done by GC-MS (Agligent Technol. 6890N/Agligent Technol. 5973Network Mass Selective Detector).

\section{Results and discussion}

\subsection{Chemical composition and the texture property}

The chemical compositions and BET data of $\mathrm{Cu} / \mathrm{Al}_{2} \mathrm{O}_{3}, \mathrm{Cu}-\mathrm{Zn} / \mathrm{Al}_{2} \mathrm{O}_{3}$ and $\mathrm{Cu}-\mathrm{Zn}-\mathrm{Cr}_{3} / \mathrm{Al}_{2} \mathrm{O}_{3}$ catalysts were listed in table 1. From ICP-AES results, the copper content was $11.2 \mathrm{wt} . \%$ for $\mathrm{Cu} / \mathrm{Al}_{2} \mathrm{O}_{3}$ and $\mathrm{Cu}-\mathrm{Zn} / \mathrm{Al}_{2} \mathrm{O}_{3}, 12.4$ wt. \% for $\mathrm{Cu}-\mathrm{Zn}-\mathrm{Cr}_{3} / \mathrm{Al}_{2} \mathrm{O}_{3}$ sample. The zinc content in $\mathrm{Cu}-\mathrm{Zn} / \mathrm{Al}_{2} \mathrm{O}_{3}$ catalyst was 16.5 wt. $\%$, and for $\mathrm{Cu}-\mathrm{Zn}-\mathrm{Cr}_{3} / \mathrm{Al}_{2} \mathrm{O}_{3}$ was $16.2 \mathrm{wt} \%$. The chromium content in $\mathrm{Cu}-\mathrm{Zn}-\mathrm{Cr}_{3} / \mathrm{Al}_{2} \mathrm{O}_{3}$ catalyst was $2.74 \mathrm{wt} . \%$. The results of metal contents were close to those of initially calculated ones. The BET surface areas of $\mathrm{Cu} / \mathrm{Al}_{2} \mathrm{O}_{3}, \mathrm{Cu}-\mathrm{Zn} / \mathrm{Al}_{2} \mathrm{O}_{3}$ and $\mathrm{Cu}-\mathrm{Zn}-\mathrm{Cr}_{3} / \mathrm{Al}_{2} \mathrm{O}_{3}$ catalysts were $187.8,126.6$ and $124.7 \mathrm{~m}^{2} / \mathrm{g}$, respectively. A large amounts of doped $\mathrm{Zn}$ in $\mathrm{Cu} / \mathrm{Al}_{2} \mathrm{O}_{3}$ resulted in the surface area decrease significantly, while only slight decrease in surface area could be found as few chromium were introduced into $\mathrm{Cu}-\mathrm{Zn} / \mathrm{Al}_{2} \mathrm{O}_{3}$ catalyst. The decrease in surface area, total pore volume and pore size indicated that not only the metallic oxide particulates were dispersed on the alumina support surface but also they could be accreted to inner wall of the pore channel. 
Table 1. Compositions and textural properties of $\mathrm{Cu} / \mathrm{Al}_{2} \mathrm{O}_{3}, \mathrm{Cu}-\mathrm{Zn} / \mathrm{Al}_{2} \mathrm{O}_{3}$ and $\mathrm{Cu}-\mathrm{Zn}-$ $\mathrm{Cr} / \mathrm{Al}_{2} \mathrm{O}_{3}$ catalysts.

\begin{tabular}{|c|c|c|c|c|c|c|c|}
\hline \multirow[b]{2}{*}{ Catalyst } & \multicolumn{4}{|c|}{ Composition/wt. \% } & \multirow[b]{2}{*}{$\mathrm{S}_{\mathrm{BET}} / \mathrm{m}^{2} \mathrm{~g}^{-1}$} & \multirow[b]{2}{*}{$\mathrm{V} / \mathrm{cc} \mathrm{g}^{-1}$} & \multirow[b]{2}{*}{$D / \mathrm{nn}$} \\
\hline & $\mathrm{Cu}$ & $\mathrm{Zn}$ & $\mathrm{Cr}$ & Al & & & \\
\hline $\mathrm{Cu} / \mathrm{Al}_{2} \mathrm{O}_{3}$ & $11 \cdot 2$ & - & - & $47 \cdot 0$ & 187.8 & 0.3558 & $7 \cdot 576$ \\
\hline $\mathrm{Cu}-\mathrm{Zn} / \mathrm{Al}_{2} \mathrm{O}_{3}$ & $11 \cdot 2$ & $16 \cdot 5$ & - & 34.7 & $126 \cdot 6$ & 0.2312 & $7 \cdot 416$ \\
\hline $\mathrm{Cu}-\mathrm{Zn}-\mathrm{Cr}_{3} / \mathrm{Al}_{2} \mathrm{O}_{3}{ }^{\mathrm{a}}$ & 12.4 & $16 \cdot 2$ & 2.74 & 31.9 & $124 \cdot 7$ & $0 \cdot 1984$ & $6 \cdot 269$ \\
\hline
\end{tabular}

${ }^{\mathrm{a}} \mathrm{Chromium}$ initial calculated content is $3 \mathrm{wt} . \%$. ${ }^{\mathrm{b}}$ calculated from ICP-AES
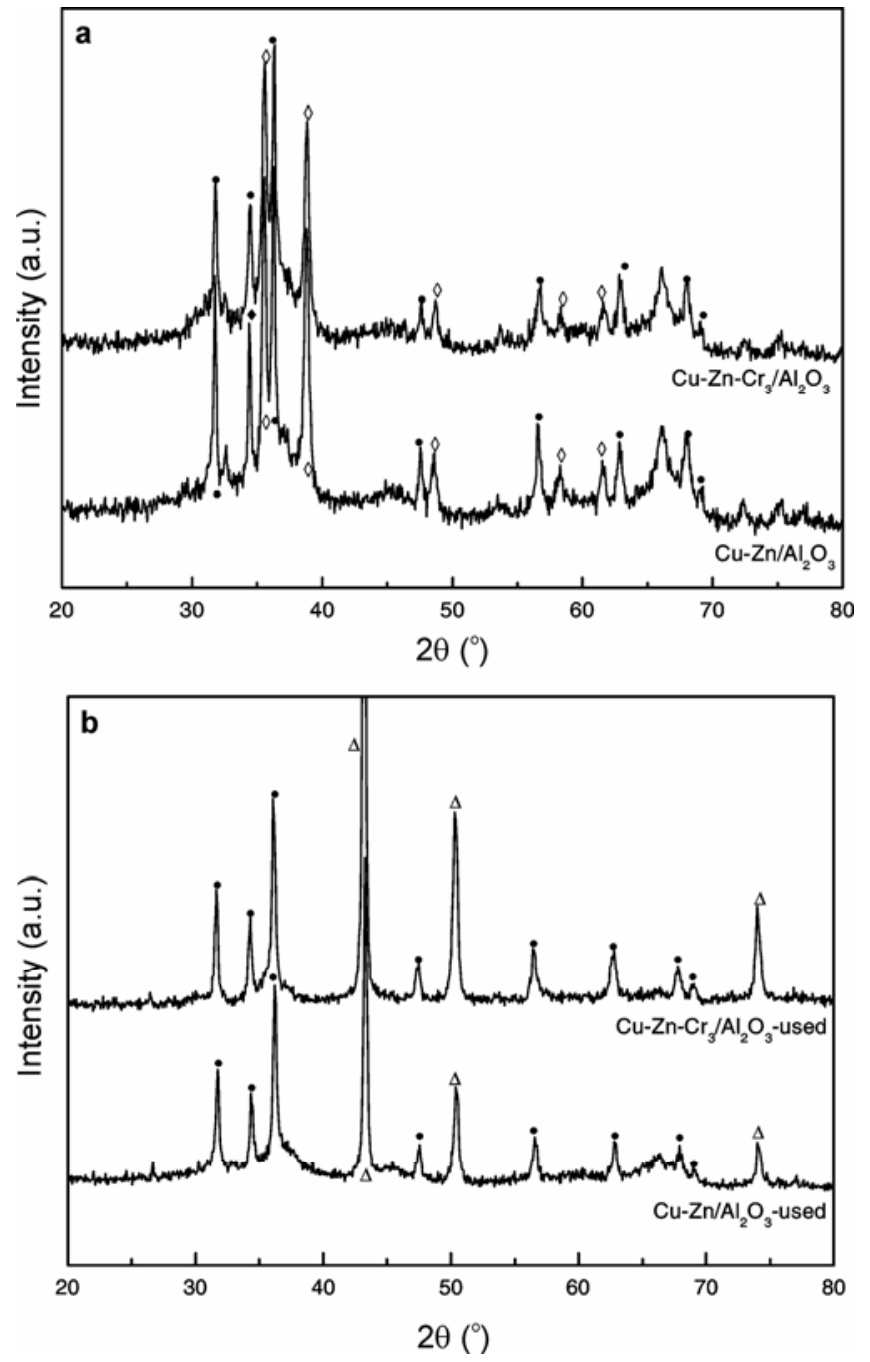

Figure 2. a, XRD patterns of fresh $\mathrm{Cu}-\mathrm{Zn} / \mathrm{Al}_{2} \mathrm{O}_{3}$ and $\mathrm{Cu}-\mathrm{Zn}-\mathrm{Cr}_{3} / \mathrm{Al}_{2} \mathrm{O}_{3}$ catalysts. b, XRD patterns of used $\mathrm{Cu}-$ $\mathrm{Zn} / \mathrm{Al}_{2} \mathrm{O}_{3}$ and $\mathrm{Cu}-\mathrm{Zn}-\mathrm{Cr}_{3} / \mathrm{Al}_{2} \mathrm{O}_{3}$ catalysts.

\subsection{Phase composition of the catalyst}

XRD analysis was employed to investigate the crystal of the elements of the catalyst samples, and the XRD patterns of the fresh catalysts and used catalysts were obtained (see figures $2 \mathrm{a}$ and $\mathrm{b}$ ). Both patterns of two fresh catalyst samples revealed highly characteristic reflection of $\mathrm{ZnO}$ and $\mathrm{CuO}$. While the chromium species, generally existing as spinel in $\mathrm{Cr}$ rich $\mathrm{Cu}-\mathrm{Zn}$-Cr catalytic system, ${ }^{24-26}$ had very weak intensity, which probably could explain that the amorphous chromium species existed in the catalyst with low chromium content.

Figure $2 \mathrm{~b}$ showed XRD patterns of used $\mathrm{Cu}-\mathrm{Zn} / \mathrm{Al}_{2} \mathrm{O}_{3}$ and $\mathrm{Cu}-\mathrm{Zn}-\mathrm{Cr}_{3} / \mathrm{Al}_{2} \mathrm{O}_{3}$ catalysts. For $\mathrm{Cu}-\mathrm{Zn} / \mathrm{Al}_{2} \mathrm{O}_{3}$ catalyst, the diffraction peaks of metallic copper phase were observed as the effect of pre-reduction with $\mathrm{H}_{2}$ and $\mathrm{ZnO}$ could not be reduced. As to be expected, there was no obvious diffraction peak of chromium species because of its possible amorphous state in $\mathrm{Cu}-\mathrm{Zn}-\mathrm{Cr}_{3} / \mathrm{Al}_{2} \mathrm{O}_{3}$ catalyst, which may be enhanced by $\mathrm{H}_{2}$ pre-treatment.

\subsection{Chemical state of the surface elements by XPS}

The surface analysis of the catalysts and the chemical state of the elements were evaluated by XPS technique, the catalyst samples were pre-treated by using hydrogen gas at $380^{\circ} \mathrm{C}$ for $2 \mathrm{~h}$ prior to analysis. The XPS spectra of the $\mathrm{Cu} 2 \mathrm{p}_{3 / 2}$ of $\mathrm{Cu}-\mathrm{Zn} / \mathrm{Al}_{2} \mathrm{O}_{3}$ and $\mathrm{Cu}-\mathrm{Zn}-\mathrm{Cr}_{3} / \mathrm{Al}_{2} \mathrm{O}_{3}$ catalysts were shown in figure 3. The copper oxide displayed strong shake-up peak near $935.0 \mathrm{eV}$, which is the characteristic of $\mathrm{Cu}^{2+}$ species. Another means of identifying $\mathrm{Cu}^{2+}$ cation was the satellite peak, about $8 \mathrm{eV}$ on the high binding energy side, due to the shake-up transition by ligand $\rightarrow$ metal $3 d$ charge transfer, which cannot occur in $\mathrm{Cu}^{+}$and $\mathrm{Cu}^{0}$ because of their fully filled $3 d$ shell. ${ }^{27-29}$ The peaks around $932.4 \mathrm{eV}$ were assigned to the cuprous cations and/or metallic copper. ${ }^{30} \mathrm{In}$ the XPS spectrum of $\mathrm{Cu}-\mathrm{Zn}-\mathrm{Cr}_{3} / \mathrm{Al}_{2} \mathrm{O}_{3}$ catalyst, the $\mathrm{Cu}^{2+}$ species with considerable peak intensity were detected, because the reduced sample was exposed to air before XPS examination, the detected amounts of copper species in the sample did not characterize the surface composition of the catalyst under the reaction conditions. Instead, these data illustrated partial reoxidation of the catalyst when the sample 
conditioned in reaction environment was exposed to air at room temperature. ${ }^{31}$ This low-temperature reoxidation apparently affected only a thin surface layer, because XRD analysis did not detect copper oxides in the reduced sample. The XPS analysis results suggested that the metallic copper content increased significantly on the catalyst surface and the introduction of chromium enhanced the reduction compared to the catalyst without chromium.

\subsection{The reducibility for the catalyst}

The TPR profiles of $\mathrm{Cu} / \mathrm{Al}_{2} \mathrm{O}_{3}, \mathrm{Cu}-\mathrm{Zn} / \mathrm{Al}_{2} \mathrm{O}_{3}$ and $\mathrm{Cu}-\mathrm{Zn}-\mathrm{Cr}_{3} / \mathrm{Al}_{2} \mathrm{O}_{3}$ catalysts were presented in figure 4. It was shown that the $\mathrm{Cu} / \mathrm{Al}_{2} \mathrm{O}_{3}$ catalyst had two reduction peaks detected at 251 and $297^{\circ} \mathrm{C}$, which could be assigned to $\mathrm{Cu}^{2+} \rightarrow \mathrm{Cu}^{+}$and $\mathrm{Cu}^{+} \rightarrow \mathrm{Cu}^{0}{ }^{32}$ Two similar TPR patterns, different from that of $\mathrm{Cu} / \mathrm{Al}_{2} \mathrm{O}_{3}$ catalyst, were observed in $\mathrm{Cu}-\mathrm{Zn} / \mathrm{Al}_{2} \mathrm{O}_{3}$ and $\mathrm{Cu}-\mathrm{Zn}-\mathrm{Cr}_{3} / \mathrm{Al}_{2} \mathrm{O}_{3}$ catalysts with only one reduction peak assigned the reduction of $\mathrm{Cu}^{2+}$ direct to $\mathrm{Cu}^{0}$ under different reduction temperatures.

The reduction peak area was in proportion to the reducible copper content for the copper-based catalyst. The variation of reduction peak area indicated that the catalyst reducibility was modified by the addition of promoter. From the results of the quantitative calculation, the $\mathrm{Cu}-\mathrm{Zn}-\mathrm{Cr}_{3} / \mathrm{Al}_{2} \mathrm{O}_{3}$ catalyst sample displayed the higher peak area than that of $\mathrm{Cu}-\mathrm{Zn} / \mathrm{Al}_{2} \mathrm{O}_{3}$ catalyst, corresponding to larger amounts of hydrogen consumption, which suggested that more copper oxides were enriched on the catalyst surface. The reduction temperature shifted to

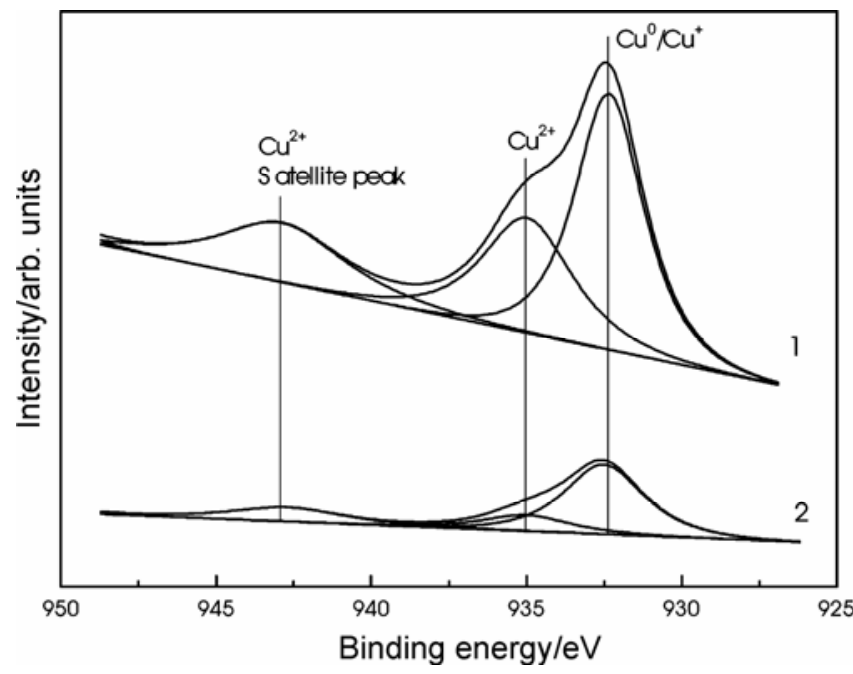

Figure 3. XPS spectra of $\mathrm{Cu}-\mathrm{Zn} / \mathrm{Al}_{2} \mathrm{O}_{3}$ and $\mathrm{Cu}-\mathrm{Zn}$ $\mathrm{Cr}_{3} / \mathrm{Al}_{2} \mathrm{O}_{3}$ catalysts. lower temperature side also indicated that the $\mathrm{Cu}^{2+}$ species were easily reduced to lower valency species by promotion of chromium. ${ }^{33-36}$ As a result, larger number of metallic $\mathrm{Cu}$ could be reduced, corresponding to larger peak intensity and peak area proportion of metallic $\mathrm{Cu}$ in XPS spectra.

\subsection{Cu surface area, dispersion and $\mathrm{Cu} / \mathrm{CuO}$ crystallite size}

$\mathrm{Cu}$ surface area and dispersion, are important parameters for $\mathrm{Cu}$-based catalyst, are generally obtained by $\mathrm{N}_{2} \mathrm{O}$ chemisorption. ${ }^{37,38}$ Copper dispersion $\left(D_{\mathrm{Cu}}\right)$, defined as the ratio of $\mathrm{Cu}$ exposed at the surface to total, was calculated from the amount of $\mathrm{H}_{2}$ consumed in the TPR process of $\mathrm{Cu}_{2} \mathrm{O} \rightarrow \mathrm{Cu}$. Starting from the $D_{\mathrm{Cu}}$ value, $\mathrm{Cu}$ metal surface area (MSA) was calculated. ${ }^{39}$

$$
\operatorname{MSA}\left(\mathrm{m}^{2} g_{\mathrm{Cu}}^{-1}\right)=\frac{\mathrm{Mol}_{\mathrm{H}_{2}} \cdot \mathrm{SF} \cdot N_{\mathrm{A}}}{10^{4} \cdot \mathrm{C}_{\mathrm{M}} \cdot \mathrm{W}_{\mathrm{cu}}},
$$

where $\mathrm{Mol}_{\mathrm{H}_{2}}, \mathrm{SF}, N_{\mathrm{A}}, C_{\mathrm{M}}$ and $W_{\mathrm{Cu}}$ are moles of hydrogen experimentally consumed per unit mass of catalyst $\left(\mu \mathrm{mol}_{\mathrm{H}_{2}} \mathrm{~g}^{-1}\right.$ cat $)$, stoichiometric factor (2), Avogadro's number $\left(6.022 \times 10^{23} \mathrm{~mol}^{-1}\right)$, number of surface $\mathrm{Cu}$ atoms per unit surface area $\left(1.47 \times 10^{19}\right.$ atoms $\mathrm{m}^{-2}$ ), and $\mathrm{Cu}$ content (wt.\%), respectively. The $\mathrm{O} / \mathrm{Cu}$ ratio is assumed to be $1 / 2(\mathrm{SF}=2)$ on the basis of UPS results, ${ }^{39}$ which proved that after oxidation with $\mathrm{N}_{2} \mathrm{O}$ at temperatures up to $100-120^{\circ} \mathrm{C}$,

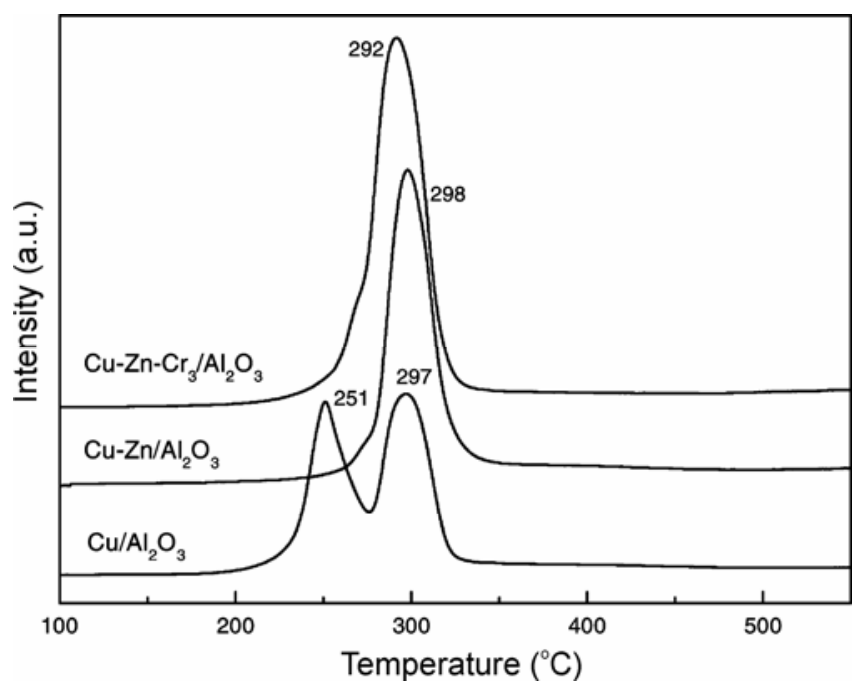

Figure 4. TPR profiles of $\mathrm{Cu} / \mathrm{Al}_{2} \mathrm{O}_{3}, \mathrm{Cu}-\mathrm{Zn} / \mathrm{Al}_{2} \mathrm{O}_{3}$ and $\mathrm{Cu}-\mathrm{Zn}-\mathrm{Cr}_{3} / \mathrm{Al}_{2} \mathrm{O}_{3}$ catalysts. The chromium initial calculated content was 3 wt. $\%$ in $\mathrm{Cu}-\mathrm{Zn}-\mathrm{Cr}_{3} / \mathrm{Al}_{2} \mathrm{O}_{3}$ catalyst. 
Table 2. Surface characteristics of dispersed copper catalysts.

\begin{tabular}{lcccc}
\hline & \multicolumn{4}{c}{$\mathrm{TPR}-\mathrm{N}_{2} \mathrm{O}$ passivation method } \\
\cline { 2 - 5 } Catalyst & Surface $\mathrm{Cu}$ content $\left(\mu \mathrm{mol} / \mathrm{g}_{\text {cat }}\right)$ & $\mathrm{Mol}_{\mathrm{H} 2}\left(\mu \mathrm{mol} / \mathrm{g}_{\text {cat }}\right)$ & $\mathrm{MSA}\left(\mathrm{m}^{2} / \mathrm{g}_{\mathrm{Cu}}\right)$ & $D_{\mathrm{Cu}}(\%)$ \\
\hline $\mathrm{Cu}-\mathrm{Zn} / \mathrm{Al}_{2} \mathrm{O}_{3}$ & $8 \cdot 0$ & $4 \cdot 0$ & $183 \cdot 1$ & 28.4 \\
$\mathrm{Cu}-\mathrm{Zn}-\mathrm{Cr}_{3} / \mathrm{Al}_{2} \mathrm{O}_{3}$ & $12 \cdot 2$ & $21 \cdot 9$ & 358.8 & $55 \cdot 7$ \\
\hline
\end{tabular}

Table 3. Crystallite size variation via $\mathrm{H}_{2}$ treatment for $\mathrm{Cu}-\mathrm{Zn} / \mathrm{Al}_{2} \mathrm{O}_{3}$ and $\mathrm{Cu}-\mathrm{Zn}-\mathrm{Cr}_{3} / \mathrm{Al}_{2} \mathrm{O}_{3}$ samples.

\begin{tabular}{lcc}
\hline Catalyst & $\mathrm{CuO}(202)[\mathrm{nm}]$ & $\mathrm{Cu}(200)[\mathrm{nm}]$ \\
\hline $\mathrm{Cu}-\mathrm{Zn} / \mathrm{Al}_{2} \mathrm{O}_{3}$ & $31 \cdot 0$ & - \\
$\mathrm{Cu}-\mathrm{Zn}-\mathrm{Cr}_{3} / \mathrm{Al}_{2} \mathrm{O}_{3}$ & $31 \cdot 2$ & - \\
$\mathrm{Cu}-\mathrm{Zn} / \mathrm{Al}_{2} \mathrm{O}_{3}$ used & - & 28.8 \\
$\mathrm{Cu}-\mathrm{Zn}-\mathrm{Cr}_{3} / \mathrm{Al}_{2} \mathrm{O}_{3}$ used & - & $27 \cdot 0$ \\
\hline
\end{tabular}

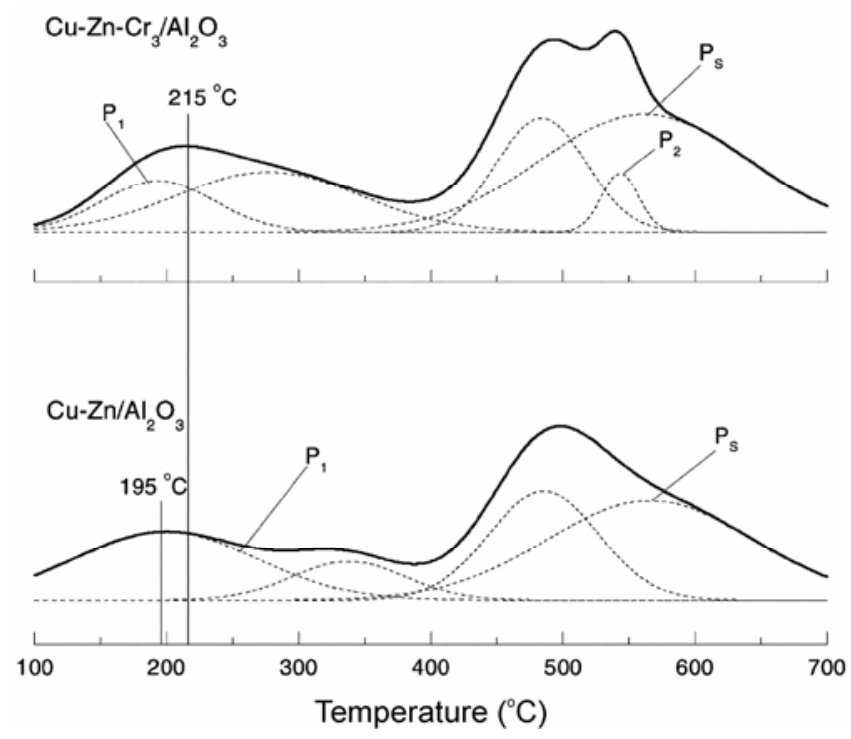

Figure 5. $\mathrm{NH}_{3}-\mathrm{TPD}$ curves for $\mathrm{Cu}-\mathrm{Zn} / \mathrm{Al}_{2} \mathrm{O}_{3}$ and $\mathrm{Cu}-\mathrm{Zn}-\mathrm{Cr}_{3} / \mathrm{Al}_{2} \mathrm{O}_{3}$ samples. The TPD curves were deconvolved using a Gaussian shaped function. The solid lines are the TPD curves and the dashed lines are the fitting curves.

the surface copper is primarily in the $\mathrm{Cu}^{+}$oxidation state. The results from $\mathrm{N}_{2} \mathrm{O}$ chemisorption were summarized in table 2. It was shown that the $\mathrm{Cr}$-promoted $\mathrm{Cu}-\mathrm{Zn} / \mathrm{Al}_{2} \mathrm{O}_{3}$ displayed larger value of surface $\mathrm{Cu}$ content, corresponding to larger amount of $\mathrm{H}_{2}$ consumption and $\mathrm{Cu}$ surface area (MSA) which increased by almost 1 time. So did the $\mathrm{Cu}$ dispersion.

The crystallite size of $\mathrm{CuO}$ and $\mathrm{Cu}$ may be estimated from the values of the full-width at halfmaximum (FWHM) of the (202) and (200) diffrac- tion peaks by means of the Scherrer equation $L=0.89 \lambda \beta(\theta) \cos \theta$, where $L$ is the crystallite size, $\lambda$ is the wavelength of the radiation used, $\theta$ is the Bragg diffraction angle, and $\beta(\theta)$ is the FWHM. ${ }^{40}$ The results are given in table 3 . For the fresh samples, the crystallite size value of $\mathrm{CuO}$ of $\mathrm{Cu}-\mathrm{Zn}$ $\mathrm{Cr}_{3} / \mathrm{Al}_{2} \mathrm{O}_{3}$ catalyst was slightly bigger than that of $\mathrm{Cu}-\mathrm{Zn} / \mathrm{Al}_{2} \mathrm{O}_{3}$ catalyst, which may be responsible for the decrease to a small extent in surface area as described in table 1 . The $\mathrm{CuO}$ phases were reduced to metallic $\mathrm{Cu}$ in $\mathrm{H}_{2}$ gas flow under the reaction conditions, the crystallite size values decreased by $7 \cdot 10 \%$ and $13.46 \%$ for $\mathrm{Cu}-\mathrm{Zn} / \mathrm{Al}_{2} \mathrm{O}_{3}$-used and $\mathrm{Cu}-\mathrm{Zn}-$ $\mathrm{Cr}_{3} / \mathrm{Al}_{2} \mathrm{O}_{3}$-used samples, respectively. It was suggested that the reducibility of $\mathrm{Cu}-\mathrm{Zn} / \mathrm{Al}_{2} \mathrm{O}_{3}$ catalyst was improved significantly by adding chromium promoter, the smaller $\mathrm{Cu}$ particles generated larger metallic $\mathrm{Cu}$ surface area and dispersion, resulting in the $\mathrm{Cu}$ particles enriched on the catalyst surface but no sintering. ${ }^{31}$

\subsection{The amount of acid sites and acid strength distribution of the catalyst}

$\mathrm{NH}_{3}$-TPD analysis was carried out in order to investigate the amount of acid sites and acid strength distribution, the TPD curves were depicted in figure 5 and the details were reported in table 4 . In the both TPD curves, four desorption regions of $100-300^{\circ} \mathrm{C}$, $300-400^{\circ} \mathrm{C}, \quad 400-590^{\circ} \mathrm{C}$ and $590-700^{\circ} \mathrm{C}$, were observed. The desorption peak below $300^{\circ} \mathrm{C}$ was not ascribed to the ammonia directly adsorbed on the acid sites but for possible ammonia molecules interaction with the terminal $\mathrm{OH}$ groups on the catalyst surface, which were desorbed easily on the TPD test (this process was denoted as $P_{1}$ in figure 5) ${ }^{41,42}$ The high-temperature peaks $\left(400-590^{\circ} \mathrm{C}\right)$ were assigned to desorption of $\mathrm{NH}_{3}$ from the strong acid sites. ${ }^{43}$ The difference between the TPD curves for $\mathrm{Cu}-\mathrm{Zn} / \mathrm{Al}_{2} \mathrm{O}_{3}$ and $\mathrm{Cu}-\mathrm{Zn}-\mathrm{Cr}_{3} / \mathrm{Al}_{2} \mathrm{O}_{3}$ catalysts was found, it was single peak for that of $\mathrm{Cu}-\mathrm{Zn} / \mathrm{Al}_{2} \mathrm{O}_{3}$ while it was double peaks for that of $\mathrm{Cu}-\mathrm{Zn}-$ 
Table 4. Acid strength distribution for $\mathrm{Cu}-\mathrm{Zn} / \mathrm{Al}_{2} \mathrm{O}_{3}$ and $\mathrm{Cu}-\mathrm{Zn}-\mathrm{Cr}_{3} / \mathrm{Al}_{2} \mathrm{O}_{3}$ catalysts and their catalytic performances for 2-MP synthesis.

\begin{tabular}{lcccccc}
\hline & \multicolumn{5}{c}{ Acidity $\left(\mathrm{NH}_{3}\right.$ uptake, $\left.\mathrm{mmol} / \mathrm{g}\right)$} & \\
\cline { 2 - 5 } Catalyst & $100-300$ & $300-400$ & $400-590$ & $590-700^{\circ} \mathrm{C}$ & Total acidity & 2-MP selectivity (\%) \\
\hline $\mathrm{Cu}-\mathrm{Zn} / \mathrm{Al}_{2} \mathrm{O}_{3}$ & 0.78 & 0.21 & 2.37 & 0.48 & 3.84 & 68.0 \\
$\mathrm{Cu}-\mathrm{Zn}-\mathrm{Cr}_{3} / \mathrm{Al}_{2} \mathrm{O}_{3}$ & 1.08 & 0.12 & 2.41 & 0.42 & 4.03 & 84.8 \\
\hline
\end{tabular}

Table 5. Effect of chromium content on synthesis of 2-methylpyrazine.

\begin{tabular}{|c|c|c|c|c|c|c|c|c|}
\hline \multirow[b]{2}{*}{ Catalyst } & \multirow[b]{2}{*}{ ED conv. } & \multirow[b]{2}{*}{ PG conv. } & \multicolumn{6}{|c|}{ Selectivity (\%) } \\
\hline & & & $\mathrm{Lb}$ & Py & 2-MP & 2-MPIP & Alkyl pyrazines & Others \\
\hline $\mathrm{Cu} / \mathrm{Al}_{2} \mathrm{O}_{3}$ & $76 \cdot 7$ & $80 \cdot 2$ & $11 \cdot 0$ & $14 \cdot 79$ & $53 \cdot 35$ & $5 \cdot 02$ & $14 \cdot 01$ & $1 \cdot 83$ \\
\hline $\mathrm{Cu}-\mathrm{Zn} / \mathrm{Al}_{2} \mathrm{O}_{3}$ & $88 \cdot 1$ & $90 \cdot 5$ & $2 \cdot 82$ & $21 \cdot 47$ & $68 \cdot 02$ & $4 \cdot 26$ & $2 \cdot 06$ & $1 \cdot 38$ \\
\hline $\mathrm{Cu}-\mathrm{Zn}-\mathrm{Cr}_{1} / \mathrm{Al}_{2} \mathrm{O}_{3}$ & $93 \cdot 6$ & $96 \cdot 1$ & $3 \cdot 65$ & $10 \cdot 58$ & $81 \cdot 46$ & $2 \cdot 23$ & $0 \cdot 82$ & $1 \cdot 25$ \\
\hline $\mathrm{Cu}-\mathrm{Zn}-\mathrm{Cr}_{3} / \mathrm{Al}_{2} \mathrm{O}_{3}$ & $97 \cdot 9$ & 100 & $3 \cdot 43$ & $6 \cdot 99$ & 84.75 & $2 \cdot 42$ & $1 \cdot 01$ & $1 \cdot 40$ \\
\hline $\mathrm{Cu}-\mathrm{Zn}-\mathrm{Cr}_{5} / \mathrm{Al}_{2} \mathrm{O}_{3}$ & 95.7 & $98 \cdot 7$ & $3 \cdot 32$ & $6 \cdot 59$ & $84 \cdot 64$ & $3 \cdot 04$ & $1 \cdot 04$ & $1 \cdot 37$ \\
\hline $\mathrm{Cu}-\mathrm{Zn}-\mathrm{Cr}_{7} / \mathrm{Al}_{2} \mathrm{O}_{3}$ & $95 \cdot 4$ & $98 \cdot 2$ & $3 \cdot 08$ & $8 \cdot 17$ & $82 \cdot 62$ & $2 \cdot 86$ & $1 \cdot 37$ & 1.90 \\
\hline
\end{tabular}

$\mathrm{ED}=$ ethylene diamine, $\mathrm{PG}=$ propylene glycol, $\mathrm{Lb}=$ lower boiling point components, $\mathrm{Py}=$ pyrazine, 2-MP = 2-methylpyrazine, 2-MPIP = 2-methylpiperazine. Reaction conditions: atmosphere, temperature $=380^{\circ} \mathrm{C}$, time on stream $=2 \mathrm{~h}, \mathrm{LHSV}=1 \mathrm{~h}^{-1}, \mathrm{ED}: \mathrm{PG}=1: 1$ (mol) in $50 \mathrm{wt} . \%$ aq. solution

$\mathrm{Cr}_{3} / \mathrm{Al}_{2} \mathrm{O}_{3}$ catalyst. The overlapped peaks indicated that there might be stronger acid sites (denoted as $\mathrm{P}_{2}$ ) in $\mathrm{Cu}-\mathrm{Zn}-\mathrm{Cr}_{3} / \mathrm{Al}_{2} \mathrm{O}_{3}$ sample, the deconvolution indeed showed that there were two different strength acid sites with different desorption temperature. The each TPD curve displayed a broadening shoulder peak (denoted as $\mathrm{P}_{\mathrm{s}}$ ) around $600^{\circ} \mathrm{C}$, corresponding to the formation of strongly Lewis acid sites generated by $\mathrm{Zn}^{2+}$, which was identified that the low-temperature peak $\left(100-300^{\circ} \mathrm{C}\right)$ was widened and shifted to high-temperature side. ${ }^{17,44,45} \mathrm{Cu}-\mathrm{Zn}-\mathrm{Cr}_{3} / \mathrm{Al}_{2} \mathrm{O}_{3}$ showed an increase of $\mathrm{NH}_{3}$ desorption from 0.78 to $1.08 \mathrm{mmol} / \mathrm{g}$ compared to $\mathrm{Cu}-\mathrm{Zn} / \mathrm{Al}_{2} \mathrm{O}_{3}$ (table 4). The total acidity also increased by $4.9 \%$. It was shown that the increased acidity displayed a considerable effect on the catalytic performance, the selectivity of 2-MP increased by $24.7 \%$.

\subsection{Catalytic synthesis of 2-methylpyrazine from ED and $P G$}

3.7a Effect of chromium content on catalytic performance: The effects of $\mathrm{Cu}-\mathrm{Zn} / \mathrm{Al}_{2} \mathrm{O}_{3}$ catalyst promoted by chromium of different concentration on the conversions of reactants and the products selectivities were studied and the results were summarized in table 5. It is clear from the table that the catalysts containing chromium produced less amount of pyrazine, alkyl pyrazine and intermediate product, 2-methylpiperazine as compared with those of the catalysts without chromium. The selectivity of 2-methylpyrazine increased to $84.75 \%$ over $\mathrm{Cu}-\mathrm{Zn}$ $\mathrm{Cr}_{3} / \mathrm{Al}_{2} \mathrm{O}_{3}$ catalyst compared to $68.02 \%$ on $\mathrm{Cu}-$ $\mathrm{Zn} / \mathrm{Al}_{2} \mathrm{O}_{3}$ catalyst. Keeping the copper and zinc concentration constant, $15 \mathrm{wt} . \%$ and $20 \mathrm{wt} \%$ respectively, the effects of different chromium concentration were studied at the same conditions, and the results showed that the optimum concentration of chromium was $3 \mathrm{wt} . \%$. The results of BET revealed that chromium promoted the dispersion of active copper species and acted as a fence to separate active species from congregating, addition of chromium promoter was helpful for dehydration-cyclization and dehydrogenation of ethylene diamine and propylene glycol to 2-methylpyrazine. Further studies were carried out over $\mathrm{Cu}-\mathrm{Zn}-\mathrm{Cr}_{3} / \mathrm{Al}_{2} \mathrm{O}_{3}$ catalyst, as it showed good conversion of ethylene diamine and propylene glycol and selectivity of 2-methylpyrazine.

$3.7 \mathrm{~b}$ Influence of reaction temperature: Figure 6 showed that the effect of reaction temperature on reactants conversions and products distribution, the reaction was preformed over $\mathrm{Cu}-\mathrm{Zn}-\mathrm{Cr}_{3} / \mathrm{Al}_{2} \mathrm{O}_{3}$ catalyst for $2 \mathrm{~h}$ time on stream at a LHSV of $1 \mathrm{~h}^{-1}$. The 
ethylene diamine conversion increased with the reaction temperature from $87.5 \%$ at $340^{\circ} \mathrm{C}$ to $98.1 \%$ at $420^{\circ} \mathrm{C}$. The selectivity of 2-methylpyrazine was up to maximum $83 \cdot 12 \%$ at $380^{\circ} \mathrm{C}$. Only a small amount of lower boiling point components was detected in products, whose concentration was higher at lower reaction temperature $\left(340^{\circ} \mathrm{C}\right) \mathrm{com}$ pared with higher reaction temperature. At higher reaction temperature, the lower boiling point components like methanol and acetaldehyde were readily reacting with piperazine and pyrazine, giving alkyl pyrazine, which resulted in decreasing slightly in concentration of lower boiling point components rather than higher to be expected. Besides, the piperazine ring structure could be easily cracked at higher reaction temperature with the concurrent formation of side reaction products and ammonia, ${ }^{18}$ which also reacted with pyrazine and 2-methylpyrazine to alkyl pyrazine. As a result, the selectivities of pyrazine, 2-methylpyrazine and 2-methylpiperazine decreased, in contrast to increased of alkyl pyrazine.

3.7c Product distribution versus molar ratio of reactants: A series of experiments were performed to determine the optimum feed ratio at $380^{\circ} \mathrm{C}$ with different mole ratio of ethylene diamine and propylene glycol over $\mathrm{Cu}-\mathrm{Zn}-\mathrm{Cr}_{3} / \mathrm{Al}_{2} \mathrm{O}_{3}$ catalyst and the results were presented in table 6 . It could be found from the table that the ethylene diamine conversion decreased when the mole ratio of ethylene diamine

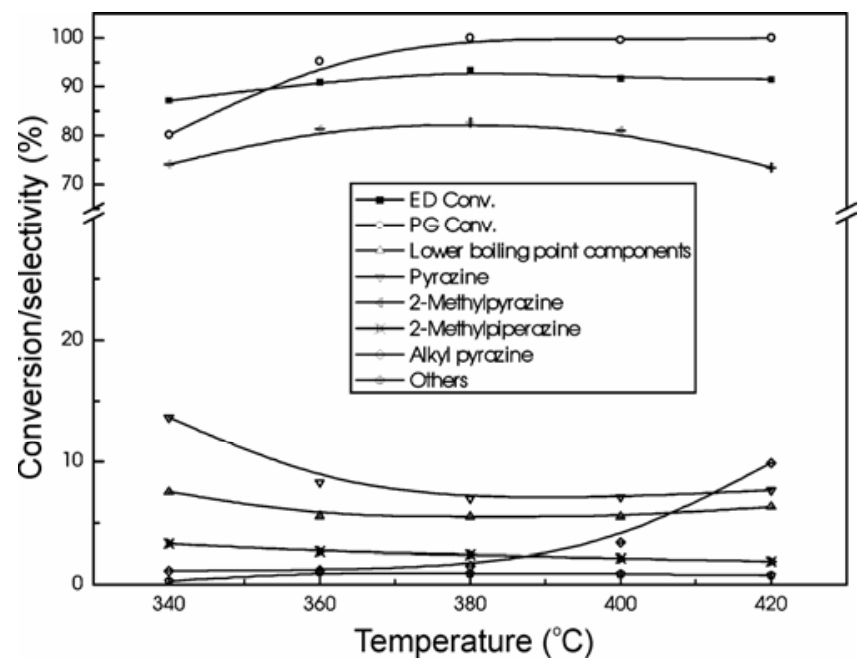

Figure 6. Influence of temperature on synthesis of 2methylpyrazine over $\mathrm{Cu}-\mathrm{Zn}-\mathrm{Cr}_{3} / \mathrm{Al}_{2} \mathrm{O}_{3}$ catalyst. Reaction conditions: atmospheric, time on stream $=2 \mathrm{~h}, \mathrm{LHSV}=$ $1 \mathrm{~h}^{-1}, \mathrm{ED}: \mathrm{PG}=1: 1$ (mol) in $50 \mathrm{wt} . \%$ aq. solution. increased. The concentration of pyrazine increased from 6.69 to $13.6 \%$ with the mole ratio from 1 to 1.5 , which was probably contributed to the selfcyclocondensation of ethylene diamine. The selectivity of 2-methylpyrazine decreased as ethylene diamine concentration increasing in the feed. It could also be noted that the formation of 2-methylpiperazine, which was the primary intermediate product, which had the same trend with 2-methylpyrazine.

3.7d Role of LHSV in synthesis of 2-methylpyrazine: It was demonstrated that the effect of liquid hourly space velocity (LHSV) on the formation of 2-methylpyrazine in figure 7. It is clear that the conversions of the reactants as well as selectivity for 2-methylpyrazine decreases with increase in LHSV. However, the increase in selectivity of 2-methylpiperazine, the main intermediate product, indicated that dehydrogenation had not been well performed due to the less contact time. At low LHSV, 2-methylpyrazine and pyrazine were the major products. As LHSV increased from $1 \mathrm{~h}^{-1}$ to $2.4 \mathrm{~h}^{-1}$, the selectivity of 2-methylpyrazine decreased from $83 \cdot 1$ to $65 \cdot 0 \%$, that of alkyl pyrazines increased resulting from dehydrogenation of pyrazine, piperazine and their methyl derivative and alkylation of that with the lower boiling point components like acetone, lower alcohols and acetaldehyde, which were easily formed at a high LHSV value.

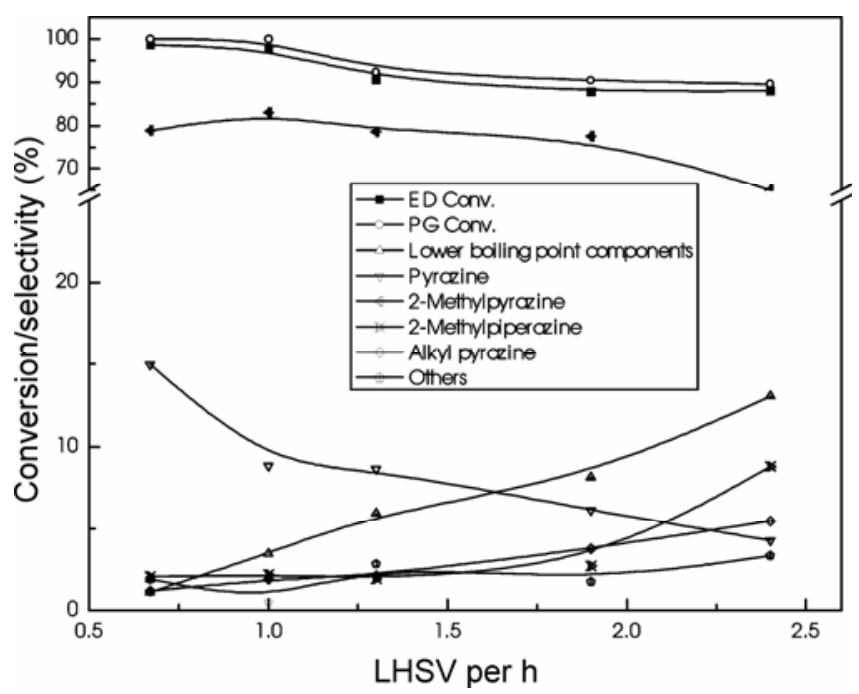

Figure 7. Influence of LHSV on synthesis of 2methylpyrazine over $\mathrm{Cu}-\mathrm{Zn}-\mathrm{Cr}_{3} / \mathrm{Al}_{2} \mathrm{O}_{3}$ catalyst. Reaction conditions: atmosphere, temperature $=380^{\circ} \mathrm{C}$, time on stream $=2 \mathrm{~h}, \mathrm{ED}: \mathrm{PG}=1: 1 \mathrm{~mol})$ in $50 \mathrm{wt} . \% \mathrm{aq}$. solution. 
Table 6. Effect of molar ratio of ethylene diamine and propylene glycol on synthesis of 2-methylpyrazine over $\mathrm{Cu}-$ $\mathrm{Zn}-\mathrm{Cr}_{3} / \mathrm{Al}_{2} \mathrm{O}_{3}$ catalyst.

\begin{tabular}{|c|c|c|c|c|c|c|c|c|}
\hline \multirow[b]{2}{*}{ Molar ratio $\mathrm{ED}: \mathrm{PG}$} & \multirow[b]{2}{*}{ ED conv. } & \multirow[b]{2}{*}{ PG conv. } & \multicolumn{6}{|c|}{ Selectivity (\%) } \\
\hline & & & $\mathrm{Lb}$ & Py & 2-MP & 2-MPIP & Alkyl pyrazines & Others \\
\hline $1: 1 \cdot 5$ & $100 \cdot 0$ & $95 \cdot 2$ & $5 \cdot 27$ & $2 \cdot 54$ & $85 \cdot 88$ & $2 \cdot 81$ & 1.76 & 1.76 \\
\hline $1: 1.2$ & $98 \cdot 5$ & $98 \cdot 8$ & $2 \cdot 96$ & $5 \cdot 21$ & $86 \cdot 26$ & 2.73 & 1.66 & $1 \cdot 20$ \\
\hline $1: 1$ & $97 \cdot 9$ & $100 \cdot 0$ & $3 \cdot 47$ & $6 \cdot 87$ & $85 \cdot 09$ & $2 \cdot 18$ & 1.89 & 0.49 \\
\hline $1 \cdot 2: 1$ & $92 \cdot 4$ & $97 \cdot 5$ & 3.59 & $8 \cdot 19$ & $82 \cdot 24$ & $2 \cdot 26$ & 3.09 & 0.64 \\
\hline $1 \cdot 5: 1$ & $79 \cdot 8$ & $97 \cdot 1$ & 3.99 & $13 \cdot 64$ & $75 \cdot 71$ & 1.84 & $4 \cdot 05$ & 0.78 \\
\hline
\end{tabular}

$\mathrm{ED}=$ ethylene diamine, $\mathrm{PG}=$ propylene glycol, $\mathrm{Lb}=$ lower boiling point components, $\mathrm{Py}=$ pyrazine, $2-\mathrm{MP}=$ 2-methylpyrazine, 2-MPIP $=2$-methylpiperazine. Reaction conditions: atmosphere, temperature $=380^{\circ} \mathrm{C}$, time on stream $=2 \mathrm{~h}, \mathrm{LHSV}=1 \mathrm{~h}^{-1}$, water $=50 \mathrm{wt} . \%$ in the reactants.

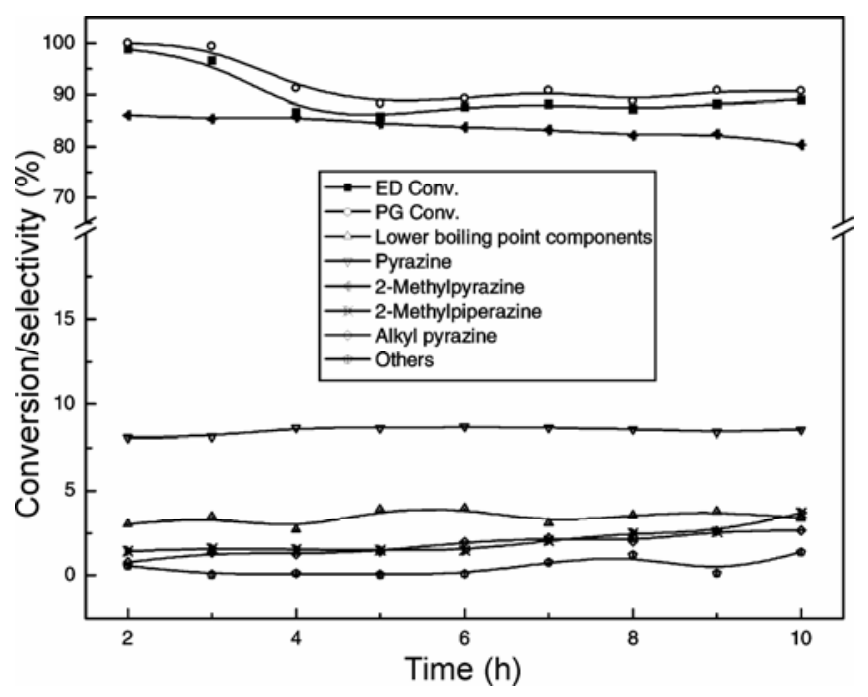

Figure 8. Influence of time on synthesis of 2-methylpyrazine over $\mathrm{Cu}-\mathrm{Zn}-\mathrm{Cr}_{3} / \mathrm{Al}_{2} \mathrm{O}_{3}$ catalyst. Reaction conditions: atmosphere, temperature $=380^{\circ} \mathrm{C}, \mathrm{LHSV}=1 \mathrm{~h}^{-1}$, $\mathrm{ED}: \mathrm{PG}=1: 1$ (mol) in $50 \mathrm{wt} . \%$ aq. solution.

3.7e Relationship between catalytic activity and time on stream: The stability was investigated over $\mathrm{Cu}-\mathrm{Zn}-\mathrm{Cr}_{3} / \mathrm{Al}_{2} \mathrm{O}_{3}$ catalyst for $10 \mathrm{~h}$ (see figure 8). Initially, the deactivation was faster, the conversion of ethylene diamine dropped sharply from 97.9 to $90 \%$ in $4 \mathrm{~h}$ and kept constant till the end $(10 \mathrm{~h})$. The selectivity of 2-methylpyrazine decreased from 86.2 to $80.3 \%$, that of 2 -methylpyrazine and pyrazine was over $90 \%$. At the end of the period of this run, the selectivity of 2-methylpiperazine increased to a little extent, which indicated that dehydrogenation was weakened. The results showed the high activity of composite catalyst in conversion of ethylene diamine and high selectivity and stability of 2methylpyrazine.

\section{Conclusions}

The novel $\mathrm{Cr}$-modified $\mathrm{Cu}-\mathrm{Zn} / \mathrm{Al}_{2} \mathrm{O}_{3}$ catalysts were prepared by a 3-step impregnation method. The $\mathrm{N}_{2}$ adsorption/desorption tests showed that the addition of chromium had little effect on the surface area and pore diameter, only evident changes were observed in pore volume. Considering the influences of chromium on the catalytic performance, the better catalytic activity (selectivity of 2-MP $>80 \%$ ) and reaction stability could be obtained compared with those of the samples without chromium. It suggested that chromium acted the role of structure promoter. XRD results suggested that chromium species might exist in catalyst as amorphous state. The dispersion of active site $\mathrm{Cu}$ increased by almost 1 time and the total acidity was significantly improved by $4.7 \%$ after of addition chromium promoter; furthermore, catalytic activity was improved. The chromium promoted catalyst displayed better reducibility compared to the catalyst without chromium according to the results of XPS, $\mathrm{N}_{2} \mathrm{O}$ chemisorption and TPR measurements.

The catalytic activity for 2-methylpyrazine synthesis by cyclo-dehydrogenation of ethylene diamine and propylene glycol was carried out at $380^{\circ} \mathrm{C}$ over the chromium-promoted $\mathrm{Cu}-\mathrm{Zn} / \mathrm{Al}_{2} \mathrm{O}_{3}$ catalysts. The $\mathrm{Cu}-\mathrm{Zn}-\mathrm{Cr}_{3} / \mathrm{Al}_{2} \mathrm{O}_{3}$ catalyst has shown good conversions of reactants, high selectivity and excellent stability of 2-methylpyrazine after reacting for $10 \mathrm{~h}$. The optimum chromium content was 3 wt.\%.

\section{Acknowledgements}

The authors wish to thank the Analysis and Test Centre of Sichuan University for ICP-AES test. Thanks are also due to Fang Guo, Fenfen Qu and Jinyan $\mathrm{Hu}$ for useful discussion. 


\section{References}

1. Cenker M, Trenton and Baxter G E 1961 US 3005820

2. Su W Y and Knifton J F 1988 US 4788289

3. Subrahmanyam, M, Kulkarni S J and Rao A V R 1995 Indian J. Chem. Technol. 2237

4. Seetharamanjaneya S P, Raghavan K V, Rao P K and Kulkarni S J 2002 US 143180 A1

5. Forni L, Stern G and Gatti M 1987 Appl. Catal. 29 161

6. Subrahmanyam M, Muralidhar G and Kulkarni S J 2000 IN 185171

7. Forni L and Pollesel P 1991 J. Catal. 130403

8. Sato K 1978 US 4097478

9. Subrahmanyam M, Muralidhar G and Verma P K 2001 IN 185482

10. Lee Y K, Park S E and Kwon Y S 1990 US 4966970

11. Shoji T, Nakaishi $T$ and Mikata M 1996 JP 08225543A

12. Balpanov D S, Krichevskii L A and Kagarlitskii A D 2001 Russ. J. Appl. Chem. 742125

13. Fedolyak G T, Morozov A V, Kagarlitskii A D, Krichevskii L A and Akad I 1990 Nauk Kaz. SSR, Ser. Khim. 685

14. Shoji T and Nakaishi T 1997 US 5693806

15. Forni L and Nestori S 1998 Stud. Surf. Sci. Catal. 41 291

16. Anand R and Rao B S 2002 Catal. Commun. 3 29

17. Anand R, Hegde S G, Rao B S and Gopinath C S 2002 Catal. Lett. 84265

18. Dixon J K 1946 US 2400398

19. Pfann HF, Greenwich and Dixon JK 1947 US 2414552

20. Park I, Lee J, Rhee Y, Han Y and Kim H 2003 Appl. Catal. A: Gen 253249

21. Park I, Rhee Y, Lee J, Han Y H, Jeon J and Kim H 2003 Res. Chem. Intermed. 29575

22. Cesar D V, Perez C A, Salim V M M and Schmal M 1999 Appl. Catal. A: Gen 176205

23. Velu S, Suzuki K and Osaki T 1999 Catal. Lett. 62 159

24. Lindstrom B, Pettersson L J and Menon P G 2002 Appl. Catal. A: Gen. 234111
25. Fujiwara M, Kieffer R, Ando H and Souma Y 1995 Appl. Catal. A: Gen. 121113

26. Fujiwara M, Ando H, Tanaka M and Souma Y 1995 Appl. Catal. A: Gen. 130105

27. Murcia-Mascaros S, Navarro R M, Gomez-Sainero L and Fierro J L G 2001 J. Catal. 198338

28. Diaz G, Perez-Hernandez R, Gomez-Cortes A, Benaissa M, Mariscal R and Fierro J L G 1999 J. Catal. 1871

29. Campos-Martin J M, Guerrero-Ruiz A and Fierro J L G 1995 J. Catal. 156208

30. Mathew T, Rao B S and Gopinath C S 2004 J. Catal. 222107

31. Ilinich O, Ruettinger W, Liu X S and Farrauto R 2007 J. Catal. 247112

32. Zhai X, Shamoto J, Xie H and Han Y 2008 Fuel 87 430

33. Tan Y, Xie H, Cui H and Han Y 2005 Catal. Today 10425

34. Chen C S, Cheng W H and Lin S S 2003 Appl. Catal. A: Gen. 23855

35. Huang L H, Chu W, Long Y, Ci Z M and Luo S Z 2006 Catal. Lett. 108113

36. Chu W, Zhang T, He C H and Wu Y T 2002 Catal. Lett. 79129

37. Guerreiro E D, Gorriz O F, Larsen G and Arrua L A 2000 Appl. Catal. A: Gen 20433

38. Turco M, Bagnasco G, Cammarano C, Senese P, Costantino U and Sisani M 2007 Appl. Catal. B: Environ. 7746

39. Gervasini A and Bennici S 2005 Appl. Catal. A: Gen 281199

40. Zhao Y, Li F, Zhang R, Evans D G and Duan X 2002 Chem. Mater. 144286

41. Mathew T, Vijayaraj M, Pal S, Tope B B, Hegde S G, Rao B S and Gopinath C S 2004 J. Catal. 227175

42. Mathew T, Tope B B, Shiju N R, Hegde S G, Rao B S and Gopinath C S 2002 PCCP 44260

43. Barthos R, Lonyi F, Onyestyak G and Valyon J 2001 Solid State Ionics 141253

44. Katada N, Endo J, Notsu K, Yasunobu N, Naito N and Niwa M 2000 J. Phys. Chem. B104 10321

45. Roessner F, Hagen A, Mroczek U, Karge H G and Steinberg K H 1993 Stud. Surf. Sci. Catal. B75 1707 